\title{
Special Issue Dedicated to Prof. Dr. Robert Verpoorte
}

\author{
Correspondence \\ Dr. Young Hae Choi \\ Natural Products Laboratory, Institute of Biology, \\ Leiden University \\ Sylviusweg 72, 2333 BE Leiden, the Netherlands \\ Phone: + 31 (0) 715274510 , Fax: + 31 (0)715274511 \\ y.choi@chem.leidenuniv.nl
}

Bibliography

DOI https://doi.org/10.1055/a-0636-0459

Planta Med 2018; 84: 833 @ Georg Thieme Verlag KG

Stuttgart · New York | ISSN 0032-0943
In 2017, Prof. Robert Verpoorte, Emeritus Professor at the Institute of Biology of Leiden University, was awarded the Egon-StahlAward in Gold from the Society for Medicinal Plant and Natural Product Research (GA), the most prestigious distinction of GA, in recognition of his outstanding scientific lifetime contribution.

Prof. Verpoorte was born on 17th May 1946 in Eindhoven, the Netherlands. He studied pharmacy at Leiden University in 19631967 and obtained a master degree in pharmaceutical sciences of Leiden University in 1970, and a PhD from the same university with a thesis on pharmacognostical studies of some African Strychnos species under the supervision of Prof. Dr. A. Baerheim Svendsen (Faculty of Pharmacy, Leiden University, the Netherlands) and Prof. Dr. F. Sandberg (Faculty of Pharmacy, Stockholm University, Sweden). By 1976, he was a senior faculty member for the faculty of Pharmaceutical Sciences, Leiden University and, in 1987, he was appointed professor and head of the department of Pharmacognosy/Plant Cell Biotechnology, Leiden University. His group was moved to the Institute of Biology in 2003 and from then up until his retirement, he remained as Professor and Head of the department of Pharmacognosy/Plant Cell Biotechnology, Section Metabolomics, Institute of Biology, Leiden University. Following his retirement in May 2011, he became Emeritus Professor of Natural Products Laboratory, Institute of Biology, Leiden University.

Prof. Verpoorte was a highly productive scientist throughout his academic career with over 770 scientific publications in the form of research papers, books, and book chapters. His research interests are very diverse, covering numerous topics related to natural products such as plant cell biotechnology, biosynthesis, chromatography, metabolomics, genetic engineering, and green technology, as well as the isolation of new biologically active compounds from natural products. His name is recognised as a pioneer in the work of the biosynthesis of indole alkaloids, NMR-based metabolomics and Natural Deep Eutectic Solvents in the field of natural product research. His scientific activities are not limited only to research but also expands into education and scientific communications. From 1990, he has been internationally involved in many educational courses in natural product research including biotechnology, biosynthesis, separation, and metabolomics. He was also very active in giving lectures at conferences and scientific meetings (as many as 15-20 times per year). In addition to this, he serves as an editorial board member to numerous scientific jour- nals. This includes his role as Editor-in-Chief for Journal of Ethnopharmacology (2003-2016), and Phytochemistry Reviews (since 2001) and executive editor of Biotechnology Letters (since 2006).

Prof. Verpoorte is one of the most gifted scientists I have ever met. The best scientists, if there is any requirement in addition to their passion for scientific truth, should be a good listener, observer, thinker and presenter. He keeps his composure and always to tries to listen carefully to those around him; partners and students. He observes what might be hidden at first glance, thinks of a solution for scientific problems in a different way to others, and then finally describes his thoughts in an easy and coherent manner. As per his favorite scientific quote, 'there are no negative results only unexpected ones', he has tackled scientific matters with his talented eye (observation), heart (passion) and brain (thinking) in an innovative way. This is one of the many reasons why his research is so diverse and innovative. He was also very keen to transfer his knowledge to students, particularly to the students in developing countries or with some social restrictions. He believes that 'the way to change the world is education, nothing else'. His educational activities have resulted in 66 doctoral theses, and he has hosted numerous postdocs and visiting scientists in his group.

For his excellent achievements, Prof. Verpoorte has received numerous scientific distinctions, honorary doctorates and professorships. After his retirement, he chose to continue leading an active life devoted to science, for which he has been invited to many scientific meetings all over the world. Also, he is a frequent lecturer on topics related to natural products chemistry, biotechnology, metabolomics and green technology.

I know that all of his remarkable scientific contributions cannot be reflected in a limited space of a journal but at least I, as a close friend who has seen him almost every day for over 15 years, had to do something. So, with the help of Prof. Veronika Butterweck (Editor-in-Chief of Planta Medica), I brought up the idea of a Special Issue dedicated to him; the positive response was immediate from all of the contributors. The result of this effort is now in the hands of the readers. I express here my deepest gratitude to all of the contributors of publications: former students, postdocs, colleagues, and friends.

Young Hae Choi 